\title{
THE BENEFITS AND PITFALLS OF THE TEACHER-MEDITATOR RELATIONSHIP
}

\section{Stuart McLeod}

Since the time of the Buddha, generations of accomplished teachers have taught students to cultivate the qualities associated with the Buddhist path; the importance of this teacher-meditator relationship is widely recognised, whether in the context of learning how to calm the mind or of facilitating insight. The relationship is also fraught with difficulty, however, particularly in those traditions where the relationship itself is the foundation of the student's practice. What are the qualities needed for a successful relationship that works for the genuine benefit of the teacher and meditator, what kind of problem causes the relationship to falter, and how can this be avoided or overcome?

What primarily sets the Buddha apart from his successors is that he discovered the path to awakening through his own efforts (notwithstanding the help he received from his first meditation instructors). But he left a considerable legacy of guidance through his oral teachings. Of the many formulations that encapsulate the essence of the Buddhist path, a pertinent one to draw upon here is the Threefold Path, which comprises:

- Ethics (Pali síla, Skt sīla) — the development of a foundation of moral conduct.

- Meditation (samādhi) - the cultivation of deep states of concentration.

- Wisdom (Pali pañña Skt prajñā)—the development of knowledge that transcends conventional levels of understanding.

Thus we see the practice of meditation as one of the cornerstones of the Buddhist path to liberation. It has remained a key element of practice for most traditions, and over time there has developed a great range of meditative disciplines. The need to learn the techniques of meditation from a teacher has, however, been a crucial factor. Drawing on the Visuddhimagga, Peter Harvey suggests:

Meditation requires personal guidance, as it is a subtle skill which cannot be properly conveyed by standardized written teachings. The teacher gets to know his pupil, guides him or her through difficulties as they occur, and guards against inappropriate use of the powerful means of self-change that meditation provides (Vism.97-110). (Harvey 1990, 244)

Contemporary Buddhism, Vol. 6, No. 1, May 2005

ISSN 1463-9947 print/1476-7953 online/05/010065-14

Routledge

(C) 2005 Taylor \& Francis Group Ltd～DOI: 10.1080/14639940500129520 
While the term 'teacher' may be generic to all schools of Buddhism, this paper also applies the familiar terms of guru in reference to Tibetan Buddhism and Rōshi for Ch'an/Zen Buddhism. A 'meditator' will be treated as synonymous with 'student' or 'disciple', although strictly speaking a student or disciple's practice would usually be understood to include more than just formal meditation.

\section{The Foundations of the Teacher-Meditator Relationship in Buddhism}

It is clear from various passages in the Pāli Canon that the early tradition placed great value upon the benefits to be derived from association with more experienced practitioners. The Udāna provides a good example:

It is to be expected of a bhikkhu who has good friends (kalyāna-mitta) ... that he will be virtuous ... that seeing danger in the smallest faults, he will train in the training rules he has accepted ... he will obtain at will, with no trouble or difficulty, talk that is effacing, a help in opening up the mind ... that he will live with energy instigated ... that he will be wise, endowed with the noble ones penetrative understanding of rise and disappearance leading to the complete ending of suffering. (Udani IV.1)

In Buddhism it is the norm for a meditator to be in direct relationship with, or at least have access to, someone of greater spiritual accomplishment who acts as teacher or guide. Indeed we can see that the development of such a relationship began with the Buddha and his first five disciples. The large growth in the number of the Buddha's followers during his lifetime of course meant that the responsibility of teaching would have continually cascaded down to the more advanced disciples.

The nature of the teacher-meditator relationship varies across the traditions, ranging from the relatively informal (e.g., with the layperson attending a beginners' meditation class) to an all-encompassing relationship such as that of the guru-disciple found in Tibetan Buddhism.

Such a relationship also exists at a seemingly more indirect level where, in most Buddhist schools, the practitioner takes the Sangha as one of the three refuges. In the Theravādin tradition the Sańgha here refers specifically to the ariyaSańgha or 'Community of Holy persons'; that is, Stream-enterers, Once-returners, Non-returners, and Arahats (Harvey 1990, 178). In Mahāyāna Buddhism, the Sangha refuge is associated with the pantheon of Buddhas and Bodhisattvas. Thus we see the Sangha, by virtue of the lofty spiritual attainment that it embodies, acting as a teacher simply by representing the ideals to which the student may aspire. The monastic Sańgha and key teachers also symbolises the third refuge.

So what exactly is involved in the process of teaching? In a non-Buddhist, generic context, Dictionary.com variously defines the verb to 'teach' as:

- To impart knowledge or skill.

- To condition to a certain action or frame of mind. 
- To cause to learn by example or experience.

- To advocate or preach.

As we will discover, the authenticity of the teacher as 'example' and the 'knowledge they impart' are key determinants in the positivity or otherwise of the relationship. Another pivotal and implicit element of a good teacher-meditator relationship is trust. Trust may be defined as 'firm reliance on the integrity, ability, or character of a person or thing' (Dictionary.com). Here, then, the meditator trusts in the authenticity of their teacher; that is, that the teacher is there to help the student in understanding the Dharma, and has their best interests at heart. The quality of trust is closely linked in religious practice with faith. In the context of the Buddhist path, faith or 'trustful confidence' (Pali saddhā, Skt sraddhā) is a foundational skilful quality that the practitioner must cultivate.

Two useful definitions of faith to note here are 'confident belief in the truth, value, or trustworthiness of a person, idea, or thing' and 'loyalty to a person or thing' (Dictionary.com). Buddhist saddhā is particularly of an affective nature, implying an attitude of trust both to the 'person' (the Buddha, the teacher, and the student herself) and the 'idea, or thing' (the Dharma). With the teacher in some traditions considered to be a living Buddha, as well as being the student's primary contact with the Dharma, the teacher often becomes a key or exclusive focus through which the meditator feels and expresses their faith. However, when the Buddha's death was imminent, he was concerned that his followers should understand that it was what he taught - the Dharma and the Vinaya (the monastic code of conduct) - and not himself that should endure:

You should live as islands unto yourselves, being your own refuge, with no one else as your refuge, with the Dhamma as an island, with the Dhamma as your refuge, no other refuge. (Mahāparinibbāna Sutta 2.26; Walshe 1987, 245)

Such an assertion appears to be at odds with later developments in Buddhism, such as the absolute faith that the disciple should place in the guru. We shall go on to consider how these various emphases upon faith in the teacher have the potential for both positive spiritual growth-and for problems.

\section{The Benefits of the Teacher-Meditator Relationship}

According to John Crook, there is one uniting factor that defines the positive role of the teacher in all Buddhist traditions:

The vehicles ... are perspectives on the Dharma with the power to induce realisation. The teacher is a facilitator of this individual process ... A great lama or a solitary yogin consulted in some remote cave only have Buddhist validity if they facilitate the insight of others. (Crook 1998, 34-5)

A brief look at the contrasting characteristics of the teacher-meditator relationship exemplified in different schools of Buddhism, as well as their similarities, will help 
elicit a deeper appreciation of the varied positive facets that may be wrapped up in the role of 'facilitator'.

\section{Theravāda Buddhism}

In the Theravāda tradition the teacher is a valued and honoured mentor worthy of great respect, a model and inspiration on the path. (Preece 2004a, 2)

Returning to the kalyāna-mittatā (good friendship) of early Buddhism identified in the Pāli Canon, Sarah Shaw outlines the benefits to the meditator of having a teacher, suggesting 'The good friend is important as someone in whom one can place trust and to whom one can talk openly about the meditation practice and problems connected with it' (Shaw 2004, 3). Citing Upatissa's Vimuttimagga, ${ }^{1}$ she adds:

Someone who goes on the path without such a guide is like someone setting out alone on a distant journey ... the good friend however, is compared to ... . an elephant trainer, a good road on which a man can take oxen, a doctor who cures diseases and removes pain, rain from heaven that moistens everything ... a father who guides his son ... or a teacher who guides his pupils. (Shaw 2004, 3)

In addition, we are told that the teacher is able to help the meditator overcome difficulties and to establish a clear path for the student to tread.

Another important benefit that the teacher offers the student is detailed in Chapter III of the Visuddhimagga: 'Explanation of taking a meditation subject' (Kammaāțthāna-gahaṇa-niddesa). Here Buddhaghosa addresses the teacher's role in assessing a pupil's temperament to help select an appropriate meditation subject. Without this assistance, we can imagine that the meditator may be in danger of practising a subject unsuited to her temperament.

\section{Ch'an/Zen Buddhism}

A different quality may be observed in the Rōshi-student relationship in the Ch'an/Zen tradition of the Mahāyāna. Crook suggests:

The master ... was to be treated with total devotion as an infallible teacher. This was conceivable because such a one had attained enlightenment through his or her practice and received a transmission to teach ... That which was to be transmitted was nothing less than the enlightenment of Buddha himself. $(1997,233)$

The importance to the Zen student of having a teacher is also noted by Shunryu Suzuki:

The purpose of studying Buddhism is not to study Buddhism, but to study ourselves. It is impossible to study ourselves without some teaching ... You 
need a teacher so that you can become independent. If you are not attached to him, the teacher will show you the way to yourself. (1970, 76-7)

The cutting edge of the relationship manifests itself through the process of dokusan (personal instruction/interview), typically in the context of intensive practice on a retreat. In the Rinzai tradition in particular, dokusan is often depicted as a highly charged, confrontational exchange between the Rōshi and student, but it may be understood more broadly as an opportunity for the student to take any practice-related problems to the teacher. However, the true benefit is believed to lie in the dynamics of the Rōshi-student exchange. The role of the Rōshi is to help facilitate the student's direct experience of the here-and-now, a breakthrough/ enlightenment experience known as kenshō or satori. The Rōshi's skill is in understanding the student's state of mind, and then assisting the conditions in which direct realisation may occur. To enable this process, trust is required on the student's part, as she must be prepared to open herself fully to the teacher. Yasutani-rōshi explains the importance of dokusan to the relationship:

The essential characteristic of dokusan is the forming of a karmic bond between teacher and disciple, the significance of which is deep in Buddhism ... Since what passes between the roshi and the student ... concerns problems of a deep and ultimate nature, only the truth must be spoken between them. (Yasutani, in Kapleau 1965, 55)

\section{Vajrayāna/mantrayāna Buddhism}

It is only in the Mantrayana approach that this relationship itself forms the basis of a spiritual evolution. (Harding, in Kongtrul 2002, 11-2)

In Tibetan Buddhism, particularly in its Tantric forms, the intensity of the teachermeditator relationship is perhaps at its greatest, and is considered of paramount importance. Indeed there is no other path for the Tantric disciple to follow than one of complete devotion to the guru. Here the qualities of faith and trust truly come centre-stage: 'The only thing to do is to pray to the guru for realisation to dawn' (Harding, in Kongtru1 2002, 22). However, the relationship must first be established through a process of careful examination of one another, precisely because the relationship is not to be entered into lightly:

Not to examine the teacher

Is like drinking poison;

Not to examine the disciple

is like leaping from a precipice. (Patrul 1994, 141)

In accepting the guru, the disciple regards him as a Buddha, and devotes himself unconditionally to the will of his teacher. It is through this process of complete surrender to the guru that we are told great benefits will arise: 
All Buddha qualities are projected and identified with the guru. Longing and devotion directed toward the guru are so intensified that ... one's heart is opened, providing the space for connection, that is, blessing, to occur. (Harding, in Kongtrul 2002, 12)

Once this connection has been established, the benefits to the disciple are noted by Patrul Rinpoche. His description of the guru has some similarities to Upatissa's portrayal of the kalyāna-mitta (Skt kalyāna-mitra).

Like a navigator, he unfailingly charts out for us the route to liberation ... Like a downpour of nectar, he extinguishes the blaze of negative emotions. Like the sun and moon, he radiates the light of Dharma and disperses the thick darkness of ignorance ... Like the wish-granting tree, he is the source of all help in this life and happiness in the next. (Patrul 1994, 142)

\section{Common Themes}

A number of positive themes can be identified in these descriptions of the teacher-meditator relationship.

- Teacher as mentor. By their getting to know one another and establishing a trustful relationship, the student accepts advice and guidance from their 'chosen' teacher. In instances where the student may be going astray, the mentor's care for him is similar to the kalyāna-mitta who is like a 'father who guides his son'.

- Teacher as instructor. The teacher gives direct Dharma instruction. His own experience of the path enables him to reflect on the student's situation and instruct appropriately, which is especially valuable when difficulties arise. The guru 'should teach each individual according to that person's needs' (Patrul 1994, 138).

- Teacher as exemplar. It has been said that the Rōshi 'is a person who has actualised that perfect freedom which is the potentiality for all human beings' (Dixon, in Suzuki 1970, 18). While such claims are not always lived up to, it can be appreciated that examples of exemplary conduct would inspire the meditator to emulate the teacher's achievements. Here we may also remind ourselves of the idea of the Śangha refuge representing the ideals to which the meditator should aspire.

- Curing of ills. The Buddha and his teachings have been likened to a physician and his medicine. Similarly, we see the kalyāna-mitta as 'a doctor who cures diseases and removes pain', and of the guru it is said that 'like a downpour of nectar, he extinguishes the blaze of negative emotions'.

- Conditioning to a certain action or frame of mind. Both the Tibetan and Zen relationships require a trusting 'surrender' to the teacher. The benefit lies in the honesty that is brought to the interaction, which is seen as an opportunity for the student's heart to open. Second, a foundational role of all Buddhist teachers 
is to help bring the student to an understanding of their own innate wisdom. The 'conditioning to a certain frame of mind' (as an aid to deconditioning it?) can be seen in the case of the Zen Rōshi, where the student may be put under great psychological pressure to help facilitate kenshō.

\section{The Pitfalls of the Teacher-Meditator Relationship}

Although we have acknowledged the mutually beneficial nature of the archetypal relationships between teacher and meditator, it is certainly the case that this ideal is often not met. Indeed, in recent times many instances have been recorded where faulty relationships have had deeply negative consequences. According to John Crook, we should not be surprised at such outcomes:

The task of Buddhism as soteriology is to replace illusion by clarity and this process is what is meant by 'enlightenment.' Yet so normal is the state of illusion that Buddhist institutions and teachers are by no means immune from it. $(1997,221)$

\section{Misplaced Faith and Misinterpretation}

We should not assume that in flawed relationships only the teacher is to blame. A common weakness that a student may bring to the relationship is a distorted faith or trust in the teacher. Earlier we defined trust as 'firm reliance on the integrity, ability, or character of a person or thing'. However, we must consider another critical aspect of both faith and trust (although true saddhä/sraddha concerns more the second than the first of these) with these further definitions:

- $\quad$ Faith-'Belief that does not rest on logical proof or material evidence'.

- Trust-'Trust implies depth and assurance of feeling that is often based on inconclusive evidence'. (Dictionary.com)

On the student's part, then, they bring an intrinsic vulnerability to the relationship through this quality of 'not knowing, but trusting'. The extent to which this vulnerability is felt and expressed will vary from student to student, and is likely to reflect the degree of responsibility they take for themselves. In our current discussion, the quality of faith that 'does not rest on logical proof' can manifest itself as blind faith in the teacher, especially if faith has not been balanced with the faculty of wisdom (paññā). Stories abound of the tremendous presence of Buddhist teachers who have attained some degree of realisation. An outward sense of charisma, authority, and equipoise will inevitably deeply affect some people. Problems may occur, however, where a student's blind, unquestioning faith leads them incorrectly to believe in their teacher's infallibility and perfection, and indeed we have seen that some traditions encourage this. Worse still, Rob Preece warns that a serious impediment to progress may be the added tendency to deliberately overlook a teacher's imperfections. This is perhaps influenced, or 
indeed encouraged, by that quality of faith which implies loyalty and allegiance. By contrast, Preece (2004b) believes that acceptance of the teacher's shortcomings allows for a much deeper relationship.

An example of how faith-driven 'surrender' to the guru may be woefully misplaced may be seen in what Chögyam Trungpa labelled 'crazy wisdom'-the ancient drubnyon Tibetan philosophy, which 'traditionally combines exceptional insight ... with a flamboyant disregard for conventional behaviour' (Bell 2002, 233). Put simply, crazy wisdom becomes a problem when teachers blatantly contravene Buddhist precepts as a result of their own shortcomings, but the naïve student misinterprets this as the actions of a Buddha.

\section{Projection (Transference and Counter-Transference)}

The language of psychoanalysis also provides some useful pointers in understanding possible dangers in the relationship. A common occurrence is for 'transference' to take place 'when unconsciously a person endows another with an attribute that actually is projected from within themselves' (Preece 2004b, 1); for example, the student fabricates a view of the teacher as a remarkable meditator. Counter-transference occurs 'when unconsciously the other takes on this projection and lives it out thereby projecting in return a counter attribute' (Preece $2004 b, 1)$, thus the teacher acts out this masquerade for the student.

\section{Dependency/Teacher as Parental Substitute}

The tendency to project onto one another is common throughout all kinds of relationships; thus on the parts of both teacher and student, a disciplined selfawareness is required. Regarding the disciple, Michele Daniel warns of:

People coming to be students of a guru as a result of unhealed childhood wounds which lead to projections on the guru as the healer/father/mother authority that will heal them or give them an excuse to maintain static regressed states because psychological work is too scary and threatening to undertake. (WebCT 2004)

In such situations, an unhealthy, passive dependency may develop upon the teacher who will 'make it all better', thus inhibiting the meditator's personal growth. Daniel continues:

These folk usually want the 'guru' to take over their personal lives for them, rather than understanding and utilizing the precious opportunity to have a wise teacher who is devoted to helping them in their Dharma practice and their progress toward awakening. (WebCT 2004)

A further danger when dependencies have been established, perhaps reflecting patterns of parental care, is that the student may begin to fear the teacher as an authority figure. 


\section{Manipulation and Psychological/Sexual Abuse of the Student}

Of course, fear may also be injected either through peer pressure, or by the teacher, to ensure that the student conforms. A potentially volatile state of affairs exists where a student susceptible to any of the aforementioned behaviours comes into contact with such a teacher who is prone to manipulating others to exercise power and control. Indeed the very fact that students in some traditions are encouraged to see their teacher as a Buddha may well contribute to such sorry outcomes, if safeguards to counteract teacher self-inflation are not in place. However, it should be said that many teachers who have strayed into manipulative or abusive behaviour probably had no deliberate intention of doing so, but rather fell prey to their own unacknowledged shortcomings.

Western Buddhism has provided a number of examples of teachers-usually the leader or senior members of an organisation-who have abused students, often through bending Buddhist teachings to accommodate personal preference. For example, the questionable promotion of homosexuality as a Dharma practice was brought to light in the Guardian newspaper's exposé of misdemeanours within the Friends of the Western Buddhist Order (FWBO), particularly relating to practices uncovered at one their centres. One can imagine the Buddha raising an eyebrow at the following advice (although note that it is no longer given by the FWBO):

It could be beneficial to change sexual orientation as a way of recognising - and liberating yourself from-your conditioning; and that a teacher/mentor could use sex as a way of opening up communication with a pupil. (Bunting 1997, 4)

\section{The Pitfalls at Work in Buddhist Institutions}

Finally, we should mention briefly the wider implications of these pitfalls as they are manifested at an institutional level. John Crook offers this warning about teachers at the head of institutions:

Such an influential person placed in charge of an institution inevitably affects his followers ... If lacking in a necessary humility, the shadow side of such a leader may become expressed institutionally with little awareness of the process among devoted followers ... It requires exceptional awareness to gain understanding of the transference and counter-transference that soon comes into play among mutually dependent persons seeking to create an institutional perspective under the eye of a powerful leader. $(1997,33)$

In recent years, similar problems have been uncovered in a number of Western Buddhist institutions under charismatic leaders. Crook has further suggested that 'some such teachers came to dominate the institutions they led, establishing neither democratic means for self criticism nor advisory boards to provide feedback' $(1997,222)$. Such problems have often been compounded by senior students denying their teacher's shortcomings, which have typically taken the 
form of inappropriate sexual conduct, psychological abuse, and financial exploitation (Bell 2002; Lachs 1994, 2).

\section{Avoiding the Pitfalls of the Teacher-Meditator Relationship}

\section{Clarifying/Owning Aims, Roles, and Commitment}

As a first step in building a successful relationship, both the meditator and teacher should be clear about any expectations and needs they may hold, and take full ownership of them. In his paper 'Scheme for Analyzing the Dynamics of a Relation with a Spiritual Teacher', Alexander Berzin, a scholar-practitioner in the Tibetan tradition, provides valuable insight into the wide-ranging motives and commitments to the relationship (also providing a useful review of our discussions thus far). Drawing upon a few of Berzin's examples, we may point to some rudimentary questions that both the teacher and meditator should be asking of themselves:

- Is the student aiming to learn to relax, gain enlightenment, or seek approval? Does he see the teacher as a professor of Buddhism, a meditation instructor, or a mentor? Does he see himself as an academic pupil, or a disciple personally guided by the teacher? Does he feel protected, whole, a servant, a member of a cult? Is he casually or deeply involved? Does he feel indebted, obligated, or that he must be loyal?

- Is the teacher aiming to preserve the Dharma and/or their lineage, plant positive seeds for the student, or exercise power and control? Does she feel she is a master, a saviour, or a humble practitioner? Is she treating the student ethically, fulfilling her duty to teach, or wanting to control their life? (Berzin 2001a, 2-5)

Clearly, then, these questions help to highlight both the positive, negative and mixed motivations apparent in the relationship. While a predisposition to any of these negative impulses is a source of potential difficulties, we can confidently predict that thorough investigation of these questions, and a shared awareness and open acknowledgement of each of these dynamics will provide the basis for a healthy relationship.

\section{Is the Teacher Ready to Teach?}

In another essay, 'Avoiding Confusion in the Spiritual Student-Teacher Relationship', Berzin outlines the qualities that a potential teacher should possess. Reflecting our earlier summary of the teacher as mentor, instructor and exemplar, these qualities include:

- A healthy relationship with his own spiritual teachers;

- More knowledge of the Dharma than the student; 
- $\quad$ Experience and some level of success in applying its methods in meditation and in everyday life;

- Ability to set an inspiring example by having: ethical self-discipline, emotional maturity and stability, sincere concern to benefit the student, patience in teaching, lack of pretence and hypocrisy. (Berzin 2001b, 2-3)

\section{Is the Meditator Ready to be a Student?}

Berzin suggests a 'ready' student should have:

- Open-mindedness, not attached to preconceptions and opinions;

- Commonsense to differentiate between what is proper and what is not;

- $\quad$ Strong interest in the Dharma and in finding a properly qualified teacher;

- $\quad$ Appreciation and respect for the Dharma and for well-qualified teachers;

- $\quad$ An attentive mind;

- A basic level of emotional maturity and stability;

- A basic sense of ethical responsibility. (Berzin 2001b, 2)

So how may these qualities of the teacher and meditator safeguard against the pitfalls identified earlier?

\section{Exercising Choice}

We are told that the meditator should be concerned with 'finding a properly qualified teacher' so maturity and commonsense will doubtless support this. With the teacher's greater knowledge and experience of the Dharma, he/she is also responsible for exercising choice; that is, whether or not to teach the meditator, whatever the level of the relationship, such as identifying a student at a beginner's meditation class who is displaying symptoms of psychological imbalance, and thus recommending that meditation may not be appropriate for them. Equally, a self-aware Rōshi might decline a particular disciple if he anticipates a potential for manipulation in the relationship that is beyond his means to control, such as a member of the opposite sex who seems to be acting flirtatiously.

\section{Checking Blind Faith, Projection/Transference, and} Dependency/Fear

On the student's part, we can see that any tendencies toward fixed preconceptions ('my teacher is a Buddha'), an inability to differentiate the skilful and unskilful, or emotional immaturity ('I need you to be the mother I never had') might lead to these negative behaviours, thus their opposites are invaluable tools to ensure the student's well-being and capacity for spiritual growth. The crucial issue here is that the teacher has sufficient self-knowledge and maturity to anticipate and recognise when such negative tendencies are at play, and bring them to the student's attention. For example, the teacher may need to return 
ownership of a quality that the student is projecting onto them, or help them rechannel the energy behind blind faith towards more skilful ends. Equally, fear of the teacher (or more specifically of the consequences of such fear) should never arise if the teacher is truly compassionate.

The recurrence of these particular pitfalls in contemporary Western Buddhism highlights the attendant dangers in misunderstanding the tradition of 'seeing one's guru as a Buddha'. This doctrine may well be in need of better explanation, and perhaps of modification, for a Western audience. For example, Rob Preece encouragingly suggests that the disillusionment a student may feel at the point where they discover their teacher is in fact imperfect is an opportunity for growth as it 'causes us to bring back our projected ideals and begin to face reality' (Preece (2004b).

\section{Avoiding Manipulation and Abuse}

There is no more obvious guide for both teacher and student to follow to avoid an abusive nature to their relationship than the five precepts (Pali pañcaśilāni, Skt pañca-sīlāni)—namely abstention from: harming living beings; taking the not given; sexual misconduct; false speech; and intoxicants.

Furthermore, the teacher's relations with their own teachers and peers is likely to be of great benefit. In reflecting upon the safety net that Tibetan Buddhist monasticism provides, John Crook says that a lama/guru:

... Really had to be above the common herd if he was to function as the tradition demanded. Doubtless falls from grace were commonly observed, but the institutional framework of peer supervision among monastics usually corrected or managed these faults ... (Crook 1997, 234)

\section{Establishing Sound Buddhist Institutions}

Finally, the openness and compassion found in healthy individual relationships also needs to be reflected at institutional level, particularly to avoid or address the kinds of problems we have documented under the rule of autocratic leaders. Sandra Bell's review of new structures implemented at the San Francisco Zen Center in the wake of misdemeanours under the abbotship of Richard Baker ${ }^{2}$ offer valuable pointers. For example, the Center's board of directors was initially comprised solely of priests ordained by Suzuki Rōshi, but now is appointed by the Center's membership. The board has now also endorsed an 'Ethical Principles and Procedures for Grievance and Reconciliation' statement produced by its Ethics Review Committee (Bell 2002, 237-8). Such procedures are now increasingly commonplace among Western Buddhist institutions.

\section{Conclusion}

It is commonly accepted in the Buddhist tradition that a meditator wishing to embark on the path should seek the guidance of a teacher. Whichever school 
the teacher represents, it is implicit in their practice that they should relay the wisdom of their personal experience with warmth and humility, to help facilitate the insight of the student. The student should be sincere in wishing to learn and progress on the path. Key to a successful relationship for the student is a heartfelt trust. In responding to this, the teacher must demonstrate genuine regard for the welfare of the meditator, communicating the Dharma in a manner appropriate to the individual.

However, the relationship may often be marred by qualities of the very delusion that both parties seek to overcome. Such problems should be anticipated by the teacher and avoided by both, through ensuring their intentions for engaging in the relationship accord with the Buddha's teachings of wisdom and compassion.

\section{ACKNOWLEDGEMENT}

The author would like to thank Professor Peter Harvey for helpful comments on this paper.

\section{NOTES}

1. Translated by Revd Ehara, Soma Thera and Kheminda Thera as The Path of Freedom (Buddhist Publication Society, Kandy, 1977).

2. The dangers of misplaced faith in the teacher, and the manipulation and abuse of students, were perfectly exemplified under Baker's leadership, resulting in instances of sexual misconduct and financial irregularities.

\section{REFERENCES}

BELL, S. 2002. Scandals in Emerging Western Buddhism. In Westward DharmaBuddhism beyond Asia, edited by C.S. Prebish, and M. Baumann. Berkeley: University of California Press, 230-42.

BERZIN, A. 2001a. Scheme for analyzing the dynamics of a relation with a spiritual teacher. Retrieved from The Berzin Archives [http://www.berzinarchives.com/ sutra/sutra_level_1/scheme_analy_spiritual_teacher_guru.html]

BERZIN, A. 2001b. Avoiding confusion in the spiritual student-teacher relationship. Retrieved from The Berzin Archives [http://www.berzinarchives.com/sutra/ sutra_level_1/avoiding_confusion_spiritual_teacher.html] Accessed May 2004.

BUNTING, M. 1997. The dark side of enlightenment. The Guardian 27 October : 2-4.

CROOK, J. 1997. Authenticity and the practice of Zen. In The Authority of Experience, edited by J. Pickering. Richmond: Curzon, 221-45.

CROOK, J. 1998. Dangers in Devotion: Buddhist cults and the tasks of a guru. New Chan Forum 18: 31-8.

DANIEL, M. 2004. 'BUDMO3, Session 29: The Role of the Teacher in Meditative Training and the Ethics of the Teacher-Pupil relationship, How Would You Assess 
the Advantages and Dangers of Placing Unquestioning Faith in a Guru or Zen Roshi?', University of Sunderland online MA Buddhist Studies, Re: Gp 1, Sn 29 edit, 1 July 2004.

Dictionary.com. Retrieved from [www.dictionary.com] Accessed May 2004.

HARVEY, P. 1990. An Introduction to Buddhism. Cambridge: Cambridge University Press. KAPLEAU, P. 1965. The Three Pillars of Zen. New York: Anchor Books.

KONGTRUL, J. 2002. Creation and Completion. Boston: Wisdom.

LACHS, S. 1994. Coming down from the Zen clouds, Toyo Gakuen University [http:// www.human.toyogakuen-u.ac.jp/ acmuller/articles/uszen3.htm] Accessed July 1994.

PATRUL. 1994. The Words of My Perfect Teacher. San Francisco \& London: Harper Collins. PREECE, R. 2004a. The teacher-student relationship (Part 1). [http://www.mudra.co.uk/ mudra_teacher_part1.html], extracted from The Noble Imperfection. The challenge of individuation in Buddhist life. Mudra Publications. Accessed June 2004.

PREECE, R. 2004b. The teacher-student relationship (Part 2). [http://www.mudra.co.uk/ mudra_teacher_part2.html], extracted from The Noble Imperfection. The challenge of individuation in Buddhist life. Mudra Publications Accessed June 2004.

SHAW, S. 2004. Unpublished work, quoted in P. Harvey, BUDMO3, Session 2: Some Principles of Meditation, Section 3.

SUZUKI, S. 1970. Zen Mind, Beginners Mind. New York \& Tokyo: Weatherhill.

UDANA, IV.1 (UD.34) Meghiya Sutta. Retrieved from Access to Insight [http://www. accesstoinsight.org/canon/sutta/khuddaka/udana/ud4-01a.html]. Accessed May 2004.

WALSHE, M. 1987. Mahāparinibbāna Sutta. The Long Discourses of the BuddhaA Translation of the Dīgha Niäkya. Boston: Wisdom.

WebCT-eLearning systems for educational institutions. [online discussion forumpassword protected] Available from: [http://webct.sundemand.ac.uk/webct/ ticket/ticket Login?action=print_login@request_uri=webct/homearea/homearea $\% 3 F]$.

Stuart McLeod, Previous student of Professor Peter Harvey, MA Buddhist studies cours leader. University of Sundeland, School of Art, Design, Media and Culture. Priestman Building, Green Terrace, Sunderland, SR1 3PZ, UK. Email: mcroberts@tinyworld.co.uk 